UTILITY: Jurnal Ilmiah Pendidikan dan Ekonomi

Volume 4, No. 2, Agustus 2020: Page 46-53

ISSN 2549-1377 (Print) || ISSN 2549-1385 (Online)

Available online at $h$ ttp://journal.stkipnurulhuda.ac.id/index.php/utility

\title{
PENGARUH MODEL PEMBELAJARAN (PBL) PROJECT BASED LEARNING TERHADAP HASIL BELAJAR MATA PELAJARAN KEWIRAUSAHAAN PESERTA DIDIK KELAS XI SMK MUHAMMADIYAH 03 SUKARAJA
}

\author{
Siti Widya Astuti ${ }^{1}$, Sigit Priyono ${ }^{2}$, dan Siti Afifah ${ }^{3}$ \\ ${ }^{123}$ Prodi Pendidikan Ekonomi STKIP Nurul Huda OKU Timur \\ *E-mail: widiaastuti@gmail.com
}

\begin{abstract}
Abstrak Penelitian ini adalah penelitian eksperimen menggunakan Quasi Eksperimen pada penelitian ini menggunakan desain Posttest-Only Control Design. Populasi dalam penelitian ini adalah seluruh peserta didik kelas XI SMK Muhammadiyah 03 Sukaraja semester ganjil tahun pelajaran 2019/2020 yang berjumlah 168 peserta didik, sedangkan sampel penelitian ini adalah peserta didik kelas $\mathrm{XI} \mathrm{TKJ}^{1}$ dan $\mathrm{TSM}^{3}$ SMK Muhammadiyah 03 Sukaraja yang berjumlah 60 peserta didik. Teknik pengumpulan data adalah tes dan angket, sedangkan analisis data menggunakan uji t.Hasil penelitian: Pertama: hasil belajar mata pelajaran kewirausahaan peserta didik yang menggunakan model pembelajaran Project Based Learning di kelas XI SMK Muhammadiyah 03 Sukaraja yaitu dari 30 peserta didik terdapat 24 peserta didik atau $80.00 \%$ memperoleh nilai kategori sedang, 4 peserta didik atau 13,33\% memperoleh nilai kategori tinggi dan 2 peserta didik atau 6,66\% memperoleh nilai kategori rendah dengan nilai rata-rata hasil angket sebesar 69,37 Kedua: hasil belajar mata pelajaran kewirausahaan peserta didik kelas XI SMK Muhammadiyah 03 Sukaraja yaitu dari 30 peserta didik terdapat 23 peserta didik atau 76,66\% memperoleh nilai kategori sedang, 5 peserta didik atau $16,66 \%$ memperoleh nilai kategori tinggi dan 2 peserta didik atau 6,66\% memperoleh nilai kategori rendah dengan nilai rata-rata hasil tes sebesar 76,93. Ketiga: pengaruh model pembelajaran Project Based Learning terhadap hasil belajar mata pelajaran Kewirausahaan peserta didik kelas XI SMK Muhammadiyah 03 Sukaraja dengan nilai regresi thitung 6,016 dan $t_{\text {tabel }} 1,703$, yang berarti jika skor angket penggunaan model pembelajaran Project Based Learning mengalami kenaikan sebesar 1, maka hasil belajar peserta $\operatorname{didik}(Y)$ akan mengalami peningkatan sebesar 27\%.
\end{abstract}

Kata Kunci: Project Based Learning, Hasil Belajar, Kewirausahaan

\section{PENDAHULUAN}

Belajar dapat diartikan sebagai perubahan pada individu yang terjadi melalui pengalaman, dan bukan karena pertumbuhan atau perkembangan tubuhnya atau karakteristik seseorang sejak lahir Trianto (2009:16). Belajar merupakan suatu proses perubahan kearah yang lebih baik. Perubahan tersebut menyangkut berbagai aspek seperti pengetahuan, ketrampilan maupun sikap. Perubahan karena belajar dipengaruhi oleh banyak faktor, baik faktor yang berasal dari dalam diri siswa (faktor 


\section{PENGARUH MODEL PEMBELAJARAN (PBL) PROJECT BASED LEARNING TERHADAP HASIL BELAJAR MATA \\ PELAJARAN KEWIRAUSAHAAN PESERTA DIDIK KELAS XI SMK MUHAMMADIYAH 03 SUKARAJA}

internal) maupun faktor yang berasal dari luar diri siswa (faktor eksternal). Faktor internal diantaranya adalah minat, bakat, motivasi siswa. Sedangkan faktor eksternal diantaranya adalah faktor metode pembelajaran, lingkungan belajar dan media pembelajaran. Salah satu faktor eksternal yang mempengaruhi belajar yaitu metode pembelajaran.

Djamarah (2010:94) mengatakan "Project Based Learning adalah cara penyajian pelajaran yang bertitik tolak dari suatu masalah kemudian dibahas dari berbagai segi yang berhubungan sehingga pemecahannya secara keseluruhan dan bermakna". Berdasarkan penjelasan tersebut, Project Based Learning merupakan bentuk pembelajaran dengan memberikan berbagai bahan pelajaran kepada peserta didik kemudian menugaskan peserta didik sehingga tujuan pembelajaran dapat tercapai dengan baik.

Pembelajaran menggunakan model pembelajaran Project Based Learning dilakukan dengan memberikan penugasan kepada peserta didik secara kelompok berbentuk proyek seperti melakukan analisis terhadap permasalahan tentang materi pembelajaran dilingkungan masyarakat (Hayati: 2017). Setiap kelompok mendapatkan bentuk permasalahan berbeda untuk dianalisis. Pelaksanaan model pembelajaran Project Based Learning menuntut pemahaman peserta didik terhadap materi pembelajaran sehingga peserta didik dapat menyelesaikan berbagai permasalahan dalam proyek dilingkungan masyarakat (Handayani: 2015). Pada akhir kegiatan pembelajaran menggunakan model pembelajaran Project Based Learning peserta didik secara berkelompok untuk menyusun laporan hasil penyelesaian permasalahan yang diberikan dan dipresentasikan. Menurut Fariroh (2015: 4) pembelajaran menggunakan model pembelajaran Project Based Learning menjadikan peserta didik terpacu untuk dapat memahami materi pembelajaran dan mengaplikasikannya dalam menyelesaikan masalah yang ditemukan dalam kehidupan sehari - hari.

Melalui langkah-langkah penerapan model pembelajaran (PBL) diharapkan peserta didik akan lebih aktif mengikuti proses pembelajaran sehingga akan meraih hasil maksimal. Masalah pembelajaran dalam model pembelajaran (PBL) diajukan kepada peserta didik harus memiliki keterkaitan satu dengan lainnya. Trinto (2010:92) mengatakan bahwa " Model pembelajaran (PBL) dipandang cocok diterapkan pada mata pelajaran Kewirausahaan yang selalu berhubungan dengan pengamalan kreatif peserta didik di masyarakat". Berdasarkan penjelasan konseptual model pembelajaran pada uraian diatas peneliti tertarik untuk mengadakan penelitian dengan judul : "Pengaruh Model Pembelajaran Project Based Learning Terhadap Hasil Belajar Mata Pelajaran Kewirausahaan Peserta Didik Kelas XI SMK Muhammadiyah 03 Sukaraja".

\section{METODE}


Penelitian ini merupakan jenis penelitian kuantitatif dengan pendekatan eksperimen (Jaedun : 2011). Pelaksanaan penelitian yakni dengan menggunakan sampel 2 kelas yang berbeda yakni kelas eksperimen dan kelas kontrol. (Diswantika : 2015) . Kelompok yang diberi perlakuan disebut kelompok eksperimen, kelompok yang tidak diberi perlakuan disebut kelompok kontrol (Sugiyono: 2013): .

Dalam penelitian ini yang menjadi variabel bebas $(X)$ adalah model pembelajaran. Model pembelajaran yang dimaksud dalam penelitian ini adalah model pembelajaran Project Based Learning (XI TKJ) dan hasil belajar (XI TSM). Dalam penelitian ini yang menjadi variabel terikat $(Y)$ adalah hasil belajar IPS peserta didik. Populasi dalam penelitian ini adalah seluruh peserta didik kelas XI SMK Muhammadiyah 03 Sukaraja yaitu XI-TKJ 1,XI-TKJ 2, XI-TKJ 3,XI-TSM 1,XI-TSM 2,XI-TSM 3 yang berjumlah 168 peserta didik. Pengambilan sampel dilakukan dengan mengambil dua kelas sampel dari enam kelas yaitu kelas XI-TKJ 1 dan XITSM3. Teknik yang digunakan dalam pengumpulan data penelitian ini adalah menggunakan Angket dan Tes. Teknik analisis data penelitian ini dengan cara menghitung nilai rata - rata (average), standar deviasi, dan menentukan tingkat kesukaran soal dengan kategori tinggi, sedang, dan rendah.

\section{HASIL DAN PEMBAHASAN}

\section{Hasil}

\section{HASIL BELAJAR}

\section{Hasil Belajar Peserta didik Menggunakan Model Project Based Learning}

Hasil belajar Kewirausahaan peserta didik yang menggunakan Model Pembelajaran Project Based Learning ditinjau dari persentase nilai kategori tinggi, sedang dan rendah dapat diketahui bahwa $13,33 \%$ memperoleh nilai dalam kategori tinggi, memperoleh nilai kategori sedang $80 \%$ sedangkan peserta didik yang memperoleh nilai kategori rendah $6,66 \%$ dengan nila ratarata hasl tes sebesar 75,52. Hasil penelitian menunjukkan bahwa hasil belajar peserta didik kelas XI-TKJ SMK Muhammadiyah 03 Sukaraja adalah Sedang. Data ini menunjukkan bahwa Model Pembelajaran Project Based Learning efektif diterapkan pada mata pelajaran Kewirausahaan karena Model Pembelajaran Project Based Learning menuntut peserta didik untuk aktif berdiskusi dengan sesama temannya, atau mengerjakan tugas kelompok dengan bimbingan atau arahan teman yang kompeten.

\section{Hasil Belajar Peserta ddik Menggunakan Model Project Based Learning}

Hasil belajar Kewirausahaan peserta didik yang menggunakan model Project Based Laerning ditinjau dari persentase nilai kategori tinggi, sedang dan rendah dapat diketahui bahwa memperoleh nilai dalam kategori tinggi 
PENGARUH MODEL PEMBELAJARAN (PBL) PROJECT BASED LEARNING TERHADAP HASIL BELAJAR MATA

PELAJARAN KEWIRAUSAHAAN PESERTA DIDIK KELAS XI SMK MUHAMMADIYAH 03 SUKARAJA

$13,33 \%$, memperoleh nilai kategori sedang $80.00 \%$ sedangkan peserta didik yang memperoleh nilai kategori rendah $6,66 \%$ dengan nila rata-rata hasil tes sebesar 75,52. Hasil penelitian menunjukkan bahwa hasil belajar peserta didik kelas XI TSM-3 SMK Muhammadiyah 03 Sukaraja adalah Sedang . Data ini menunjukkan bahwa model Project Based Learning efektif diterapkan pada mata pelajaran Kewirausahaan karena motode pemecahan masalah ini inti pembelajarannya guru mengajukan pertanyaan-pertanyaan dan siswa menjawab tentang materi yang diperolehnya.

\section{UJI PRASYARAT ANALISIS DATA}

\section{Uji Normalitas}

Uji normalitas data dengan metode Kolmogorov Smirnov, dari hasil olah data dengan menggunakan SPSS didapat hasil perhitungan sebagai berikut :

One-Sample Kolmogorov-Smirnov Test

\begin{tabular}{|c|c|c|c|}
\hline & & $\begin{array}{c}\text { MODE } \\
\mathrm{L}\end{array}$ & HASIL \\
\hline $\mathbf{N}$ & & 30 & 30 \\
\hline Normal & Mean & 69.37 & 76.93 \\
\hline $\mathbf{s}^{\mathrm{a}}$ & Std. Deviation & 6.145 & 6.767 \\
\hline Most & Absolute & .150 & .175 \\
\hline $\begin{array}{l}\text { Extreme } \\
\text { Difference }\end{array}$ & Positive & .068 & .125 \\
\hline $\mathbf{s}$ & Negative & -.150 & -.175 \\
\hline \multicolumn{2}{|c|}{ Kolmogorov-Smirnov Z } & .822 & .957 \\
\hline \multicolumn{2}{|c|}{ Asymp. Sig. (2-tailed) } & .318 & .509 \\
\hline
\end{tabular}

\section{a. Test distribution is Normal.}

Berdasarkan tabel di atas terlihat bahwa : 
$>$ Nilai signifikansi untuk variabel Model Pembelajaran PBL (X) sebesar 0,318 > 0,05 maka data pada variabel tersebut berdistribusi normal.

> Nilai signifikansi untuk variabel Hasil Belajar $(Y)$ sebesar 0,509 > 0,05 maka data pada variabel tersebut berdistribusi normal.

\section{Uji Linieritas Data}

Hasil olah data dengan SPSS 16.0 didapat hasil sebagai berikut :

ANOVA Table

\begin{tabular}{|c|c|c|c|c|c|c|c|}
\hline & & & $\begin{array}{l}\text { Sum of } \\
\text { Squares }\end{array}$ & $\mathrm{df}$ & $\begin{array}{l}\text { Mean } \\
\text { Square }\end{array}$ & $\mathrm{F}$ & Sig. \\
\hline$\underset{*}{\mathrm{HASIL}}$ & $\begin{array}{l}\text { Between } \\
\text { Groups }\end{array}$ & (Combined) & 425.200 & 16 & $\begin{array}{r}26.57 \\
5\end{array}$ & .383 & .964 \\
\hline \multirow{4}{*}{$\begin{array}{l}\text { MODE } \\
L\end{array}$} & & Linearity & 18.745 & 1 & $\begin{array}{r}18.74 \\
5\end{array}$ & .270 & .612 \\
\hline & & $\begin{array}{l}\text { Deviation from } \\
\text { Linearity }\end{array}$ & 406.455 & 15 & $\begin{array}{r}27.09 \\
7\end{array}$ & .390 & .958 \\
\hline & \multicolumn{2}{|c|}{ Within Groups } & 902.667 & 13 & $\begin{array}{r}69.43 \\
6\end{array}$ & & \\
\hline & \multicolumn{2}{|l|}{ Total } & 1327.867 & 29 & & & \\
\hline
\end{tabular}

Dari tabel di atas terlihat nilai signifikansi sebesar 0,958 > 0,05 maka dapat dikatakan bahwa ada hubungan yang linier antara variabel $X$ terhadap variabel $Y$.

Analisis Regresi

\begin{tabular}{|c|c|c|c|c|c|}
\hline \multicolumn{6}{|c|}{ Coefficients $^{a}$} \\
\hline \multirow[b]{2}{*}{ Model } & \multicolumn{2}{|c|}{$\begin{array}{l}\text { Unstandardized } \\
\text { Coefficients }\end{array}$} & \multirow{2}{*}{$\begin{array}{c}\text { Standardized } \\
\text { Coefficients }\end{array}$} & \multirow[b]{2}{*}{$\mathrm{t}$} & \multirow{2}{*}{$\begin{array}{l}\mathrm{Si} \\
\mathrm{g} .\end{array}$} \\
\hline & B & Std. Error & & & \\
\hline (Constant) & 116.600 & 1.894 & & $\begin{array}{r}61 \\
.5 \\
61\end{array}$ & $\begin{array}{r}.00 \\
0\end{array}$ \\
\hline $\begin{array}{l}\text { METODE } \\
\text { PBL }\end{array}$ & 47.233 & 1.198 & 982 & $\begin{array}{r}39 \\
.4 \\
30\end{array}$ & $\begin{array}{r}.00 \\
0\end{array}$ \\
\hline
\end{tabular}

a. Dependent Variable: HASIL BELAJAR

Berdasarkan hasil diatas maka persamaan regresinya menjadi : 
PENGARUH MODEL PEMBELAJARAN (PBL) PROJECT BASED LEARNING TERHADAP HASIL BELAJAR MATA PELAJARAN KEWIRAUSAHAAN PESERTA DIDIK KELAS XI SMK MUHAMMADIYAH 03 SUKARAJA

$\dot{Y}=116,600-0,472 X$

\section{ANALISIS KORELASI}

Dari hasil perhitungan dengan SPSS 16.0 didapat hasil sebagai berikut :

\begin{tabular}{|ll|r|r|}
\hline \multicolumn{3}{c|}{ Correlations } \\
\hline METODE & Pearson & METODE & \multicolumn{1}{c|}{ HASIL } \\
& Correlation & 1 & $-.982^{* *}$ \\
& Sig. (2-tailed) & & .000 \\
& $\mathrm{~N}$ & 30 & 30 \\
\hline HASIL & Pearson & $-.982^{* *}$ & 1 \\
& Correlation & .000 & \\
& Sig. (2-tailed) & 30 & 30 \\
& $\mathrm{~N}$ & \multicolumn{2}{|c|}{ (2-tailed). }
\end{tabular}

Dari tabel diatas terlihat nilai korelasi sebesar $-0,982$ hal ini menunjukkan bahwa hubungan antara variabel Model PBL $(X)$ dengan variabel hasil belajar $(Y)$ adalah bersifat positif atau dengan kata lain semakin meningkatnya Model Pembelajaran Project Based Learning maka akan meningkat pula hasil belajar siswa.

\section{Uji Hipotesis}

Pengujian selanjutnya yaitu uji hipotesis yang berfungsi untuk mencari makna hubungan antara variabel $X$ terhadap variabel $Y$.

a. Pengujian signifikansi dengan uji $t$

$$
\begin{aligned}
t= & \frac{\sqrt{n-2}}{\sqrt{1-r 2}} \\
& \frac{t \sqrt{30-2}}{\sqrt{1-(-0,75) 2}} \quad \frac{5,29 \underline{\underline{\underline{2}}}}{0,879} \quad=6,016
\end{aligned}
$$

berdasarkan hasil uji t diperoleh nilai $t_{\text {hitung }}$ sebesar 6,016 . Jika dibandingkan dengan nilai $t_{\text {tabel }}$ sebesar 1,703 pada taraf signifikan $5 \%$ maka nilai $t_{\text {hitung }} \geq t_{\text {tabel }}$ 
$(6,016 \geq 1,703)$ dan diperoleh nilai koefisien signifikansi sebesar 0,00 yang lebih kecil dari 0,05 maka dapat disimpulakn tolak $\mathrm{H}_{0}$ dan terima $\mathrm{H}_{\mathrm{a}}$. Oleh karena itu, hasil akhir penelitian ini adalah terdapat pengaruh yang signifikan model pembelajaran Project Based Learning terhadap hasil belajar Kewirausahaan peserta didik di kelas XI SMK Muhammadiyah 03 Sukaraja.

\section{Pembahasan}

Berdasarkan pengujian hipotesis pada penelitian ini yang menyatakan bahwa semakin baik model pembelajaran maka semakin berpengaruh secara signifikan terhadap hasil belajar mata pelajaran Kewirausahaan peserta didik kelas XI SMK Muhammadiyah 03 Sukaraja dan berdasarkan hasil penelitian Ha diterima dan Ho ditolak. Oleh karena itu, hasil akhir penelitian ini adalah terdapat pengaruh yang signifikan model pembelajaran Project Based Learning terhadap hasil belajar Kewirausahaan peserta didik di kelas XI SMK Muhammadiyah 03 Sukaraja.

\section{SIMPULAN}

Dari hasil penelitian mengenai Pengaruh Model Pembelajaran Project Based Learning terhadap Hasil Belajar Mata Pelajaran Kewirausahaan Peserta Didik Kelas XI SMK Muhammadiyah 03 Sukaraja, dapat disimpulkan sebagai berikut :

1. Model Pembelajaran Project Based Learning pada pelajaran Kewirausahaan peserta didik di kelas XI SMK Muhammadiyah 03 Sukaraja adalah sedang atau cukup yaitu dari 30 siswa terdapat 24 peserta didik $(80.00 \%)$ berada dalam kategori sedang, 4 peserta didik (13,33\%) berada dalam kategori tinggi, 2 peserta didik $(6,66 \%)$ berada dalam kategori rendah dengan nilai rata-rata angket 75,52.

2. Hasil belajar mata pelajaran Kewirausahaan peserta didik kelas XI SMK Muhammadiyah 03 Sukaraja adalah sedang yaitu dari 30 peserta didik terdapat 23 peserta didik $(76,66 \%)$ berada dalam kategori sedang, 5 peserta didik $(16,66 \%)$ berada dalam kategori tinggi dan kategori rendah sebanyak 2 peserta didik $(6,66 \%)$ dengan nilai rata-rata sebesar 83,70 .

3. Adanya pengaruh secara signifikan antara model pembelajaran Project Based Learning terhadap hasil belajar mata pelajaran Kewirausahaan peserta didik kelas XI SMK Muhammadiyah 03 Sukaraja, berdasarkan uji statistik dengan 


\section{PENGARUH MODEL PEMBELAJARAN (PBL) PROJECT BASED LEARNING TERHADAP HASIL BELAJAR MATA \\ PELAJARAN KEWIRAUSAHAAN PESERTA DIDIK KELAS XI SMK MUHAMMADIYAH 03 SUKARAJA}

menggunakan rumus $\mathrm{t}$ tabel yaitu : 6,016 $\geq 1,703$ sehingga $\mathrm{Ho}$ ditolak dan $\mathrm{Ha}$ diterima.

\section{UCAPAN TERIMAKASIH}

Penulis mengucapkan banyak terima kasih kepada semua pihak yang telah membantu dari proses awal penulisan hingga bisa terbitnya tulisan ini. Kepada teman dan sahabat yang selalu memberikan dorongan semangat untuk segera membuat tulisan. Kemudian, khsususnya bagi pengelola jurnal UTILITY yang telah bersedia menerbitkan tulisan ini.

\section{REFERENSI}

Diswantika, N. (2015). Efektivitas Teknik Self-Talk dalam Pendekatan Konseling Kognitif untuk Meningkatkan Disiplin Diri Peserta Didik (Penelitian Eksperimen Kuasi terhadap Peserta didik kelas X SMK PGRI 2 Kota Bandar Lampung) (Doctoral dissertation, Universitas Pendidikan Indonesia).

Djamarah, 2010. Strategi Belajar Mengajar. Jakarta : Rineka Cipta.

Fariroh, A., \& Anggraito, Y. U. (2015). Pengembangan Perangkat pembelajaran berbasis Problem Based Learning pada materi virus kelas X SMA. Journal of Biology education, 4(2).

Hayati, M. T. (2017). Penggunaan Model Pembelajaran Project Based Learning Untuk Meningkatkan Hasil Belajar Dan Kreativitas Peserta Didik Pada Subtema Proyek Bumi Dan Alam Semesta (Penelitian Tindakan Kelas di Kelas III di SD YKPPK Bandung) (Doctoral dissertation, FKIP Unpas).

HANDAYANI, I. D. A. T., KARYASA, D. R. N. I. W., \& SUARDANA, D. I. N. (2015). Komparasi peningkatan pemahaman konsep dan sikap ilmiah siswa SMA yang dibelajarkan dengan Model Pembelajaran Problem Based Learning dan Project Based Learning. Jurnal Pendidikan dan Pembelajaran IPA Indonesia, 5(1).

Trianto. 2009. Model Pembelajaran Inovatif Berorientasi Konstruktivistik. Jakarta: Prestasi Pustaka.

Trianto. 2010. Mendesain Model Pembelajaran Inovatif Progesif. Jakarta : Bumi Aksara.

Sugiono, 2013. Metode Penelitian Pendidikan Pendekatan Kuantitatif, Kualitatif, dan $R \& D$, bandung: Alfabeta 